\title{
戦前の北海道におけるスキーコース網の形成過程と地域形成 DEVELOPMENT PROCESS OF SKI COURSE NETWORKS AND ADJACENT AREA IN HOKKAIDO BEFORE THE SECOND WORLD WAR
}

\author{
小澤丈夫* \\ Takeo OZAWA
}

\begin{abstract}
Since modern ski was introduced in Japan in 1911, networks of ski tour courses were actively developed in Hokkaido until the Second World War. In the early stage ski courses were developed from the suburb of Sapporo and Otaru, the other area by railway stations on Hakodate line, then formed broad networks in mountains with ski huts and hot springs. As they were close to the daily life in snowy district, they should be considered as regional resources. This paper aims to clarify the development process and background of the ski course networks and adjacent area to support the further development in such regions.
\end{abstract}

Keywords : Hokkaido, Ski, Hut, Hütte, Hot Spring, Sapporo, Otaru, 北海道, スキー, 山小屋, 温泉, 小樽, 札幌

\section{1. はじめに}

昭和 10 年（1935 年） 1 月北海道帝国大学文武会スキー部（以下北 大スキー部）が発行した「札幌附近のスキーコース圖」（図 1)には、 札幌市、小樽市、定山渓温泉に及ぶ広域に、13 軒の山小屋とスキー に適したスロープを有する壮大なスキーコース網が描かれている1)。 これは、北大スキー部が、大正 15 年（1926 年）札幌市手稲山滝の沢 上流に国内初のスキーヒュッテであるパラダイスヒュッテを建設し たことを端緒に、北大スキー部部長大野精七 ${ }^{2}$ が語り、同医学部教授 山崎春雄 ${ }^{3}$ 、予科ドイツ語教師アーノルド・グブラー、スイス人建築 家マックス・ヒンデル4 ${ }^{4}$ らの協力を得て進められた、スキーッアーの 楽しさを広めるための構想 “山小屋の連鎖” 5) が具現化されたものと 捉えられる。一方、昭和 9 年 1 月札幌鉄道局が発行した「ニセコア ンヌプリを中心とするスキーコース圖」（図 2) には、ニセコアンヌ プリを中心とし、岩内町、小澤村、俱知安町、狩太村、蘭越の各駅、 明治時代に開かれた 6 箇所の温泉、スキーに適したスロープを結ぶ 広範なスキーコース網が描かれている。

日本における近代スキーの発祥は、オーストリア軍参謀少佐テオ ドール・エドラー・フォン・レルヒ（以下フォン・レルヒ）による、 明治 44 年（1911 年） 1 月〜 2 月の高田市（現上越市）、並びに明治 45 年 2 月〜 3 月の旭川市におけるスキー講習会とされるが ${ }^{6)}$ 、これか ら四半世紀足らずを経た昭和 10 年頃に、北海道の冬期山岳空間にお いて、鉄道駅・山小屋・温泉を拠点とした広域にわたるスキーコー ス網が形成されていたことになる。これらは、北海道の戦前期に開 拓された独自の冬期山岳空間であるという点だけでなく、雪国の生 活文化に密着し、道外から観光客を誘致した北海道の地域資源とし て捉えられるべきものと筆者は考える。やがて、これらのスキーコー 又網は、昭和 12 年 2 月に始まる日中戦争以降、拡充の勢いを失う。 第二次大戦後はスキーリフトの導入によるゲレンデスキーが主流に
なり、スキーコースは往事の活気を再び取り戻すことはなく、現在 利用されているスキーコースはその一部に限られている。しかし、 北海道には、例えばニセコひらふ地区や富良野市北の峰地区のよう に、地域形成がこのようなスキーコース網の形成と密接に関わって きた事例が見られる7)。今後これらの地域の価值を再評価し、地域づ くりを支援するためにも、その前史を明らかにしておく必要がある。

関連する文献や既往研究に、スキー技術の発達に関係した人物や 団体に関するもの ${ }^{5), 6), 8)}$ 、山小屋に関するもの ${ }^{9)}$ 、地理学におけるス キー集落形成についての研究10)などは見られるが、スキーコース網 と関連する地域の形成過程、実態、背景について、包括的に明らか にしたものは見られない。そこで本研究は、スキーに関する各種案 内書を史料とした文献調查をもとに、大正期から昭和期戦前の山岳 空間における地域形成の過程と背景の一端を、当時急速に拡充され たスキーコース網との関係から明らかにすることを目的としている。

対象とする文献は、北海道における近代スキーの発祥から大正期 までの史実を明らかにした中浦皓至による論文 ${ }^{11}$ 、今回筆者が管見 した鉄道省と札幌鉄道局 ${ }^{12}$ 並びに民間によって戦前に出版された一 般向け旅行案内書 ${ }^{13)}$ とスキーコース図（表 2)、スキーコースの拠点 となる山小屋を紹介した日本山岳会による『山日記』 ${ }^{14)}$ である。

\section{2. 大正期における郊外地と鉄道駅を起点としたスキーコース網の形成}

中浦論文では、大正期における北海道スキーの発展と普及におい て、札幌と小樽の 2 つの核が存在し、両者を起点にスキーコースが 開かれていった様子が述べられている。中浦論文から、札幌と小樽 におけるスキー発祥に関する記述を以下に要約する。「札幌では、明 治 45 年（1912 年）三週間にわたるフォン・レルヒの旭川講習を受講 したばかりの月寒歩兵第二十五連隊所属の三瓶勝美、松倉儀助、中 沢治平らが、 3 月 14 日から一週間月寒において軍人・民間人にスキー 


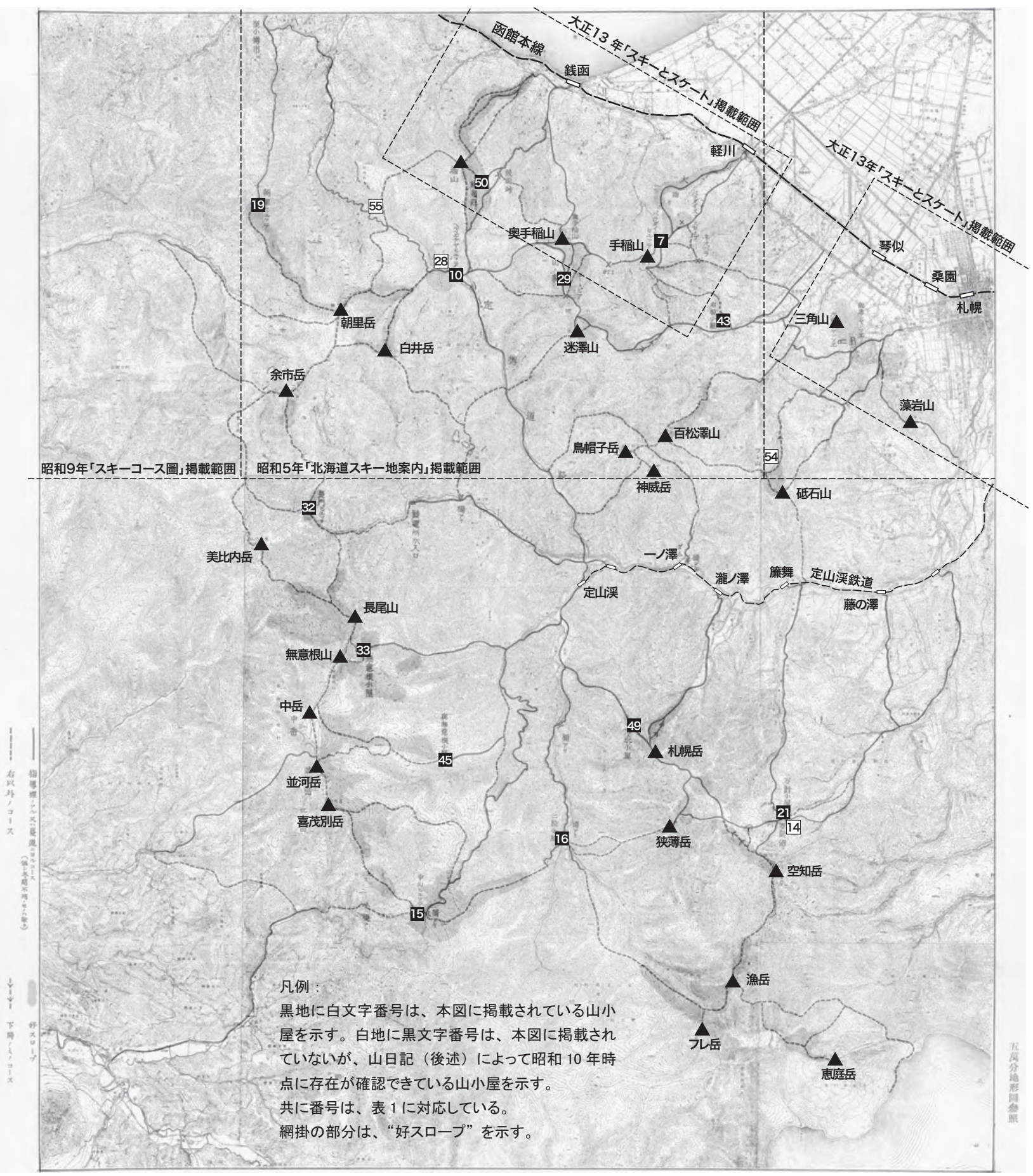

図 1 「札幌附近附近のスキーコース圖」（北大スキー部、昭和 10 年）鉄道線、駅名、山岳名、山小屋番号は筆者加筆

講習会を行う。講習会終了後には、札幌郊外の山にスキー滑走に出 かけ、3 月 29 日と 31 日の 2 回にわたり藻岩山登山を行い、これが札 幌における最初のスキー登山となり、続く 4 月 5 日には三角山登山 を行った。講習会参加者には、北大予科の学生も含まれており ${ }^{15)} 、$ 彼らは直ちに北大文武会にスキー部創設許可を申請し、大正元年 (1912 年) 9 月 21 日に認可、北大スキー部が日本で初めての大学スキー 部として設立される。同年 12 月には、北大とスキー 4 団体 ${ }^{16)}$ 合同に よるスキー講習会が札幌三角山にて開催され約 150 名が参加した。 これ以降札幌では、北大スキー部が講習会の実施、スキー技術の研究、 教程の出版など中心的な役割を担う ${ }^{17)}$ 。一方、小樽では明治 44 年 4 月に開校された小樽高等商業学校（現小樽商科大学、以下小樽高商）
初代校長渡辺龍聖が、明治 45 年 2 月に講師苫米地英俊を高田に派遣、 苫米地は 2 月 21 日に小樽にスキーを持ち帰り講習会を開催する。以 降スキーの講習が、連日小樽高商附近の地獄坂一帯で行われ小樽新 聞社によって宣伝される。旭川でのフォン・レルヒによる講習会を 受講したばかりの 3 名 $^{18)}$ もスキー技術を伝えた。同年 10 月 5 日には、 北大に半月遅れて全国 2 番目の大学スキー部として小樽高商スキー 部が設立され、以降、小樽では小樽高商や小樽新聞社が中心となっ てスキーを発展させる。このように、札幌と小樽は、ほぼ同時期に各々 独自のルートでスキーを発祥させた。」19)

さらに、同論文から、スキーコース網の形成が始まる様子に関す る記述を要約する。「藻岩山と三角山の冬期初登山後、北大スキー部 


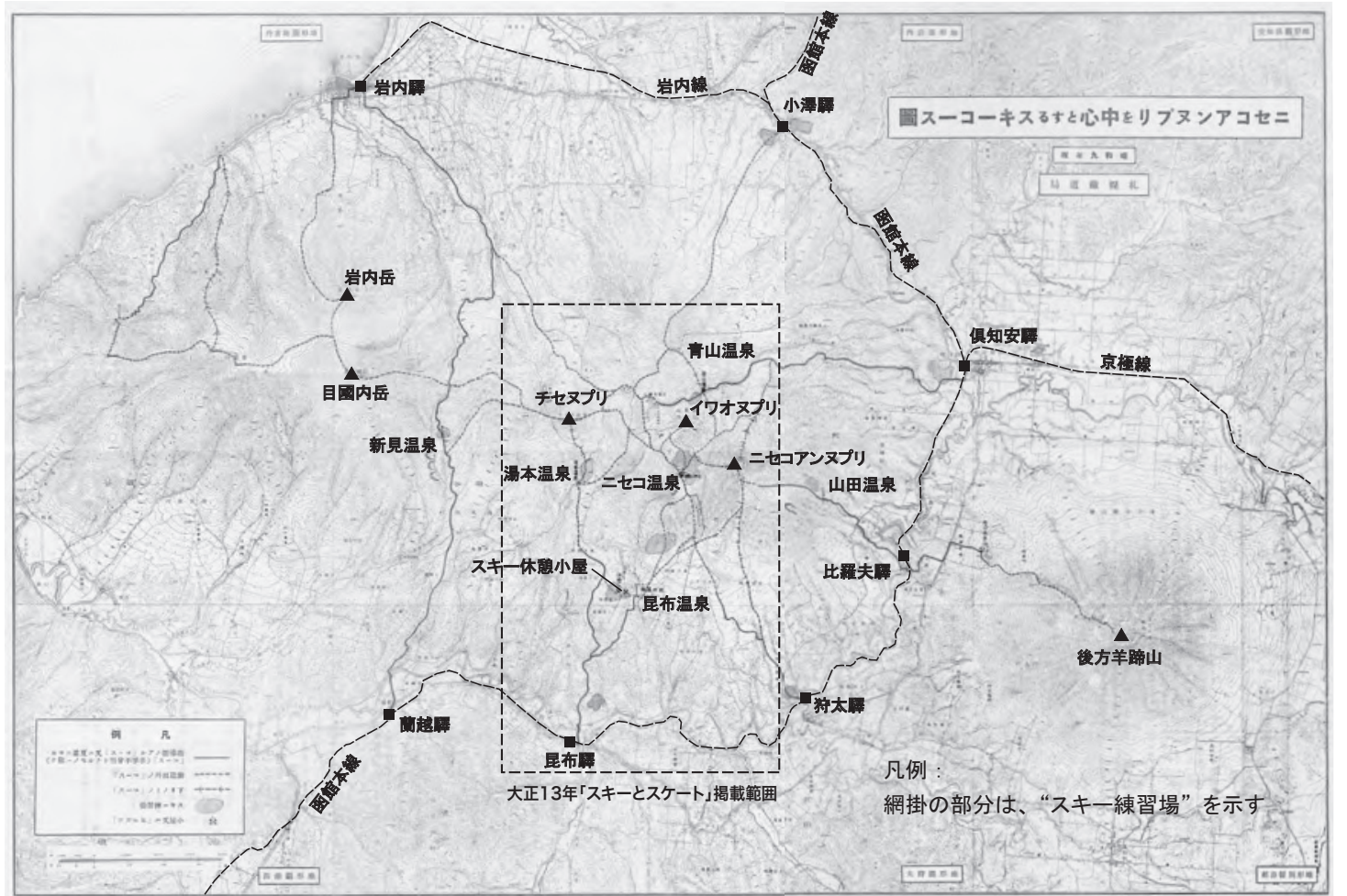

図 2 「ニセコアンヌプリを中心とするスキーコース圖」（札幌鉄道局、昭和 9 年） 鉄道線、駅名、山岳名、温泉名は筆者加筆

は大正 2 年 2 月、琴似駅から手稻山の初登頂にも成功寸る。小樽では、 大正 2 年 1 月小樽高商生青木茂弥らが、余市までスキー遠征を行い、 同月天狗山登山を成功させる。また、ノルウエー留学から最新のス キー技術を習得して帰国した北大遠藤吉三郎教授が、大正 5 年に小 樽郊外毛無山にスキールートを開き、以降小樽高商は、天狗山と毛 無山に毎年のように遠征し、大正 8 年 2 月には遠藤山ツアーを行う。 大正 5 年に始められた北大スキー部の合宿は、小樽の地獄坂附近に おいて 3 年にわたって行われたが、大正 8 年以降、北大スキー部の 合宿は、ニセコにおいて行われ、ニセコアンヌプリを中心としたス キーコースの形成に貢献する。」 ${ }^{20}$ 以上の内容を、本研究では、札幌、 小樽、ニセコアンヌプリ附近のスキーコース網形成の端緒とした。

今回筆者が調查した旅行案内書によって、北海道のスキーが初め て紹介されるのは、『鉄道旅行案内』(鉄道院、大正 7 年) 内の、札 幌附近ならびに小樽附近に「スキー好適地あり」という簡潔な記述

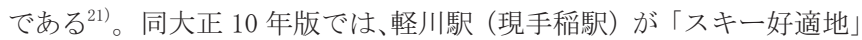
として新たに加えられる。札幌鉄道局発行の旅行案内書の中で、ス キーに関して触れられるのは、『驛附近案内標解説』(札幌鉄道局、 大正 11 年) である。これには、各駅に設置された附近の案内標の内 容が駅ごとに図示され、軽川驛で手稲山が、昆布駅で青山温泉 ${ }^{22}$ が、 「スキーの好適地」と紹介されている。『北海道各驛案内』(札幌鉄道局、 大正 12 年) では、昆布驛、比羅夫驛、小樽驛、南小樽驛、軽川驛、 琴似驛の 6 駅について、それまでの案内書より詳しく紹介され ${ }^{23)}$ 、 巻末の附録には、年中行事、釣遊地案内、狩編地案内、馬市と共に スキー地案内が記載、6 駅附近のスキー場が一覧表になっている。琴 似驛の欄には、「南半里三角山及ツッジ山附近はスキーの適地（十二 月下旬から三月上旬までがよい）として知られ、三角山には、北海 道帝国大学文武會スキー部で施設した完全なジャムプ臺もある」と 記述され、軽川驛の欄には、手稲山の説明として、「山の北麓石狩無 線電信所付近はスキーの好適地として早くから知られ、緩急各種の
斜面に富み、雪の質も良いので毎年十二月中旬から三月中旬までは 非常な盛況を呈する」と記述されている。前述の通り、すでに北大 スキー部の合宿が近傍で行われていた昆布驛は、「附近はスキーの適 地として知られてみる。」さらに附近の青山温泉について「冬はスキー 地として賑ふ。」と記述され、スキー発祥から 10 年余りの時期に、 これらの地域がスキー場として人々に親しまれていたことが伺える。

『スキーとスケート』(鉄道省 大正 13 年) は、筆者が管見した中では、 スキー場の紹介に特化して作られた初めての旅行案内書で、この中 の「本邦スキー及スケート地一覧」には、省線・社線の鉄道網・スキー 地・スケート地の位置が、拠点となる駅や附近の温泉と共に図示さ れている。道内では、函館本線に沿うニセコ附近から小樽・札幌附近、 空知、旭川、留萌、網走、野付牛（現北見）附近に、計 14 箇所のスキー 地の所在が確認できる(図 3)。さらに、地域ごとの詳細図も掲載され、 北海道では、「小樽附近スキー地」（図 4)、「札幌附近スキー地」（図 5）「手稲山附近」(図 1 に掲載範囲を図示)、「青山温泉附近スキー地」 (図 2 に掲載範囲を図示)の 4 箇所についての図版がある。記載内容は、 スキー滑走路、練習用斜面、スキー登山の対象峰、主要山岳、拠点駅、 温泉（スキー合宿地）である。以上から、大正 13 年において、札幌 と小樽の市街地と、銭函、軽川、琴似、昆布の各鉄道駅を起点にし たスキーコース網が形成されていた様子を把握できる。

\section{3. 昭和期戦前における山小屋と温泉を拠点としたスキーコース網の発展 と地域形成}

前述の通り、北大スキー部は、大正 15 年手稲山にパラダイスヒュッ テを建設する。スキーヒュッテとして専用小屋を新設する機運が盛 り上がるのは昭和 4 年〜 5 年以降で、パラダイスヒュッテは、こう した機運以前に建てられた本邦初の本格的なスイス式スキーヒュッ テであった ${ }^{24)}$ 。角幸博によると、パラダイスヒュッテは、「1925 年 5 月のスキー部幹事会でスキーヒュッテの建設が決まり、6月 14 日大 
野精七部長宅で設計および費用に関する懇談、建設地は予科教師グ ブラーが教示、ヒンデルも無償で設計協力、建具を寄付（中略） 1928 年 2 月には、秩父宮、翌年 1 月には高松宮殿下が一泊された」 25) となっており、続く昭和 2 年には、「ヒンデルとグブラーの共同出

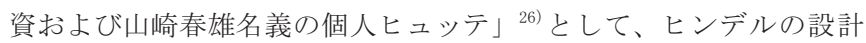
によるヘルヴェチアヒュッテが建設された。昭和 3 年には、同じく ヒンデルの設計によって空沼小屋が建設されるが、これは「1928 年 2 月秩父宮殿下からヒュッテ建設の希望があり、7 月末にプラン作成 終了、8 月初旬大野精七博士が上京して宮家に報告、8 月 25 日宮家 から工事一切を北大にて司るよう下命を受けた。」27)という経緯に よって実現したものである ${ }^{28)}$ 。のように、大正末期から昭和初期 にかけて、北大を中心とする様々な人的交流をよりどころに、札幌・ 小樽・定山渓にかけての山々にスキーに適した山小屋がつくられた。 当時の山小屋の設置状況については、日本山岳会編『山日記』 ${ }^{14)}$ によって把握できる。戦前の北海道において建設された山小屋計 81 軒 (内 3 軒は建設年不明) を表 1 に䋔めた ${ }^{29}$ 。最古のものは、モーラッ プ巡視小屋（大正 8 年）で、大正 12 年から 14 年までは、毎年 1 2 軒の山小屋が、建てられるに留まったが ${ }^{30)}$ 、大正 15 年パラダイス ヒュッテが建設されて以降、山小屋の建設数は、大正 15 年 (昭和元年) 3 軒、昭和 2 年 4 軒、昭和 3 年 5 軒、昭和 4 年 6 軒と徐々に増加し、 建設ピークである昭和 6 年に 9 軒、 7 年に 8 軒となり、その後やや減 少するが、昭和 10 年と 11 年の各 6 軒まで、多くの山小屋が北海道 内に建設される。昭和 12 年以降は、年間 3 軒程度に減少、15 年には 5 軒となるが、翌 16 年には 1 軒となり、以降山小屋は建設されない。 昭和初期のスキーコース網形成を知ることのできる旅行案内書と して、まず『スキーへ(昭和五年版)』(鉄道省 昭和 4 年) があげら れる。コース図は掲載されていないが、北海道では、青山温泉附近 スキー場、蝦夷富士附近スキー場 ${ }^{31}$ 、札幌附近スキー場、新しく加わっ た十勝猴 (吹上温泉) ${ }^{32}$ スキー場の計 4 箇所が記載されている。青 山温泉附近スキー場については、ニセコアンヌプリ周辺の温泉を拠 点として、スキーコース網が形成されている様子や、練習場の位置 が記述されている。札幌附近スキー場では、札幌市郊外の三角山と これに連なる丘陵一帯が、特に競技場として最も優れているスキー 場として、また手稲山附近として、パラダイスヒュッテ、ヘルヴェ チアヒュッテが初めて紹介され、「山小屋迴りのスキー旅行や札幌か らの日帰り、又は山小屋を根據としてのスキーなどは他では味へな いものである」と記されている。また、東京、札幌間が約 32 時間と 記述されていることから、この地域が北海道のみならず関東からも 観光客を迎えようとしたことが伺える。

『北海道スキー地案内』(札幌鉄道局、昭和 5 年) では、鉄道路線 図上で、「著名ナル山岳」が温泉と共に図示され、スキー場所在駅は 道東と道北各地にも及び計 43 箇所に増える。同書には、同年に札幌 鉄道局が建設した「奥手稲の家」の使用規定と、スキーコース図「奥 手稲の家を中心にしたるもの」(図 1 に掲載範囲を図示) が掲載され 33)、スキーコース網が、奥手稲の家、パラダイスヒュッテ、ヘルヴェ チアヒュッテ、朝里岳ヒュッテ (小樽スキー俱楽部) とともに記載 されている。大正 13 年発行のスキーコース図と比較すると、札幌・ 小樽・定山渓温泉に及ぶ広いエリアに、所有者が異なるこれら 4 軒 の山小屋を中継点としながら、スキーコース網が函館本線小樽札幌 間に近いエリアから南側の山岳地帯に拡大されたことが確認できる。
『スキーへ』(札幌鉄道局 昭和 8 年) では、スキー場の所在駅は計 72 箇所に増え、分布は全道に広く及ぶ。地域毎の図版はないが、北 海道内全域の「スキー場の名稱」として広く計 101 箇所の山岳、スロー プ、スキー場が紹介されている。主に記述されているのは、アクセ スのしかた、鉄道運賃、コースをたどるに要する時間、コースの特 徵と難易度、諸設備、スキーに適する時期などである。札幌・小樽・ 定山渓エリアを計 25 箇所のスキー場に、ニセコアンヌプリエリアを 8 籄所に分けて紹介している他、横津岳、登別温泉、空知産炭地域、

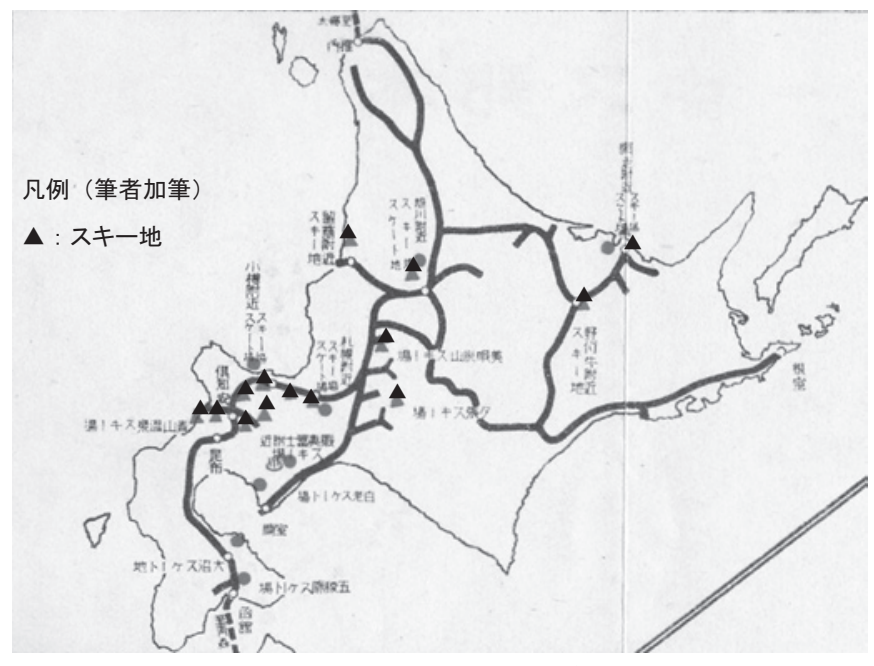

図 3 「本邦スキー及スケート地一覧」(北海道部分抜粋) 『スキーとスケート』鉄道省、大正 13 年

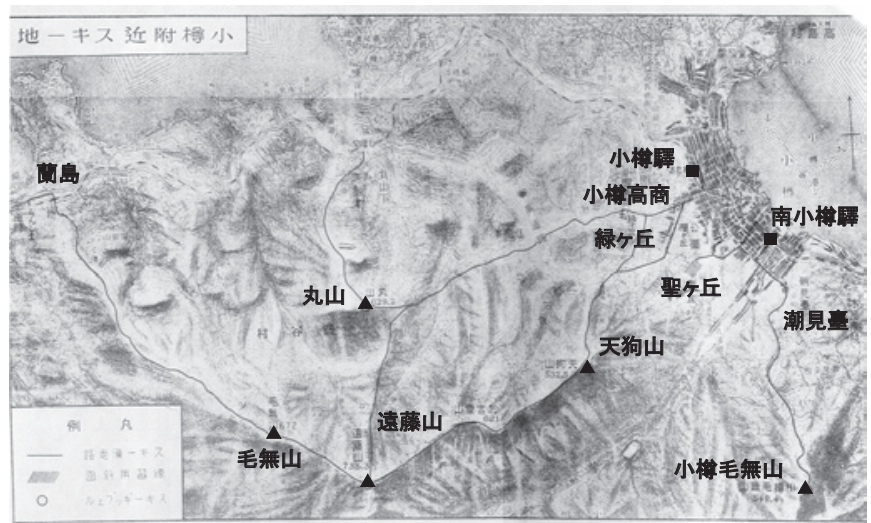

図４「小樽附近スキー地」駅、山岳名筆者加筆 『スキーとスケート』 鉄道省、大正 13 年

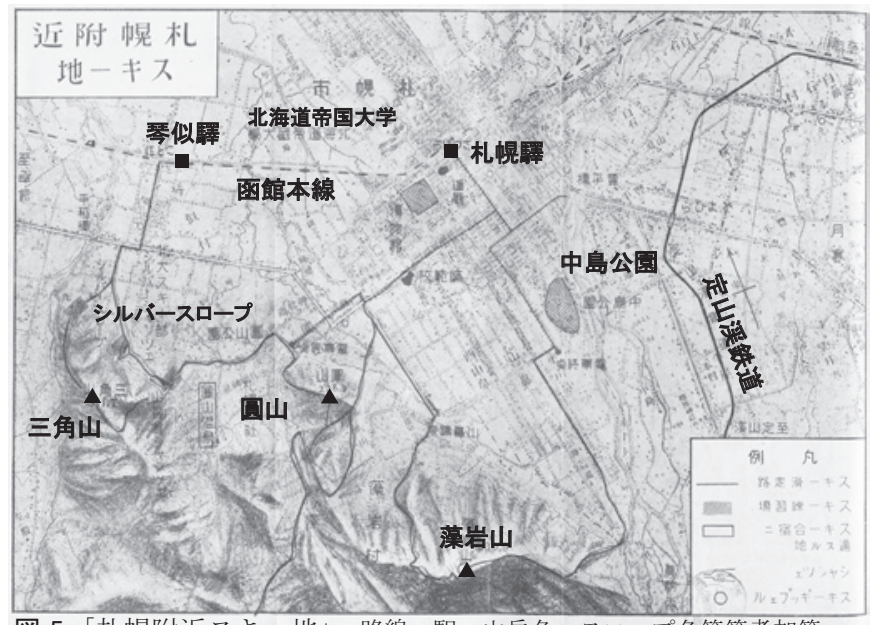

図 5 「札幌附近スキー地」 路線・駅、山岳名、スロープ名等筆者加筆 『スキーとスケート』 鉄道省、大正 13 年 
十勝岳及び上富良野周辺、名寄等についても詳しく説明している。 巻末に 17 軒の主要山小屋が挙げられており、内 15 軒は札幌・小樽・ 定山渓エリアのもの、2 軒は十勝岳のものである。

『スキーコース圖』（札幌鉄道局 昭和 9 年）では、「札幌小樽附近 スキーコース圖」に加えて、「ニセコアンヌプリを中心とするスキー コース圖」（図 2）「十勝連峯冬季登山コース圖」「藍別岳スキーコー
ス圖」が掲載されている。「札幌小樽附近スキーコース圖」（図 1 に 掲載範囲の一部を図示) では、昭和 5 年版記載の 4 つの山小屋に加 えて、白樺ヒュッテ（白樺小舎、小樽定山渓自動車会社）、右股小屋（北 海道廳）、峠ノ小屋（峠ノ小舎、小樽定山渓自動車会社）、東日ヒュッ テ（札幌スキー連盟）が記載され、昭和 5 年版スキーコース図よりも、 スキーコース数が増えネットワークが充実している。札幌の三角山

表 1 『山日記』に掲載された戦前の北海道における山小屋

\begin{tabular}{|c|c|c|c|c|c|c|c|c|c|c|}
\hline & 山小屋名 & 所在地 & 建設年 & 所属 & 収容人数 & & & 日記揭 & & \\
\hline & & & & & & S5 & S7 & S8 & S11 & S24 \\
\hline 1 & モーラップ巡視小屋 & 支笏湖畔モーラップ & 大正8年 & 帝室林野局苫小牧出張所 & 13人 & 0 & 0 & 0 & 0 & $\Delta$ \\
\hline 2 & 羊蹄山頂石室 & 羊蹄山九合目 & 大正12年 & 北海道山岳会 & $50 人$ & 0 & 0 & 0 & 0 & 0 \\
\hline 3 & 奥名寄巡視小屋 & 奥名寄農地予定地 (本流奥) & 大正12年 & 帝室林野局名寄出張所 & 8人 & 0 & 0 & & & \\
\hline 4 & 旭岳石室 & 旭岳西麓姿見池畔 & 大正13年 & 北海道庁林務課 管理·旭川森林事務所 & $40 人$ & 0 & 0 & 0 & 0 & \\
\hline 5 & 黒岳石室 & 黒岳西南約 1 km & 大正13年 & 北海道庁林務課 経営·大雪山調査会 & $60 人$ & 0 & 0 & 0 & 0 & 0 \\
\hline 6 & 十勝岳石室 & 十勝岳頂上東北の肩 & 大正14年 & 北海道庁林務課 & $30 人$ & 0 & 0 & 0 & 0 & \\
\hline 7 & パラタイイスヒュッテ & 手稲山滝ノ沢左股沢頭 & 大正15年 & 北大スキー部 & $30 人$ & 0 & 0 & 0 & 0 & 0 \\
\hline 8 & 美幌越巡視小屋 & 屈斜路湖畔近郊 & 大正15年 & 帝室林野局弟子屈出張所 & 20人 & 0 & 0 & 0 & 0 & \\
\hline 9 & 阿寒越巡視小屋 & 弟子屈阿寒の途中 & 大正15年 & 帝室林野局弟子屈出張所 & 20人 & 0 & 0 & 0 & 0 & \\
\hline 10 & ヘルヴェチアヒュッテ & 小樽内川上流、白井岳北麓 & 昭和2年 & 北大·山崎春雄教授 & 12人 & 0 & 0 & 0 & 0 & 0 \\
\hline 11 & シビナイ小屋 & 石狩川上流シビナイ川合流点 & 昭和2年 & 北大山岳部 & 8人 & 0 & & & & \\
\hline 12 & カネオベツ休泊小屋 & 大夕張カネオベツ川筋 & 昭和 2 年 & 帝室林野局夕張出張所 & 10人 & 0 & 0 & 0 & 0 & \\
\hline 13 & 吹上温泉スキー小屋 & 十勝岳西麓硫黄山南下 & 昭和2年 & 飛沢清次 & $20 人$ & 0 & 0 & 0 & 0 & $\Delta$ \\
\hline 14 & 空沼小屋 & 空沼岳中腹万計沼畔 & 昭和3年 & 秩父宮家 & 16人 & 0 & 0 & 0 & 0 & 0 \\
\hline 15 & 中山ヒユッテ & 中山殸南側 & 昭和3年 & 北海道山岳会 & $20 人$ & 0 & 0 & 0 & 0 & \\
\hline 16 & 二股造林小屋 & 豊平川上流、空沼入沢合流点 & 昭和3年 & 札幌帝室林野局 & $20 人$ & 0 & 0 & 0 & 0 & 0 \\
\hline 17 & 戸蔦別川小屋 & 戸蔦別川上流 & 昭和3年 & 北大山岳部 & 8人 & 0 & & & & \\
\hline 18 & 尾札部巡視小屋 & 尾札部川上流 & 昭和3年 & 帝室林野局弟子屈出張所 & $20 人$ & 0 & 0 & 0 & 0 & $\Delta$ \\
\hline 19 & 朝里岳ヒュッテ & 朝里岳北麓 & 昭和4年 & 小樽スキー俱楽部 & $20 人$ & 0 & 0 & 0 & 0 & $\mathrm{x}$ \\
\hline 20 & 羽幌中二股休泊小屋 & 羽幌川上流中二股 & 昭和4年 & 帝室林野局羽幌出張所 & 6人 & 0 & 0 & & & \\
\hline 21 & 万計造林小屋 & 空沼岳中腹万計沼畔 & 昭和4年 & 帝室林野局札幌出張所 & $20 人$ & 0 & 0 & 0 & 0 & 0 \\
\hline 22 & シシャモナイ巡視小屋 & 支笏湖畔シシャモナイ & 昭和4年 & 帝室林野局苫小牧出張所 & 13人 & 0 & 0 & 0 & & \\
\hline 23 & 阿寒石室 & 阿寒岳八合目 & - & - & 10人 & 0 & & & & \\
\hline 24 & 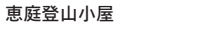 & 恵庭岳六合目 & - & 帝室林野局材木事務所 & 15人 & 0 & 0 & 0 & 0 & $\mathrm{x}$ \\
\hline 25 & 美瑛本流造林休泊小屋 & 美瑛川上流 & 昭和4年 & 帝室林野局旭川出張所 & 10人 & & & 0 & 0 & 0 \\
\hline 26 & 奥芦別巡視小屋 & 芦別川上流 & 昭和4年 & 帝室林野局上芦別出張所 & $6 人$ & & & 0 & 0 & \\
\hline 27 & ユーニイシカリ小屋 & 石狩川上流ユーニイシか川合流点 & 昭和5年 & 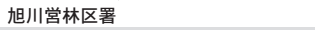 & 10人 & 0 & 0 & 0 & & \\
\hline 28 & 白槿小舎 & 小樽定山渓道路 ヘルヴェチアヒュッテ西方 & 昭和5年 & 小樽定山渓自動車会社 & $30 人$ & & & & 0 & $\mathrm{x}$ \\
\hline 29 & 奥手稲山/家 & 奥手稲の山の南方、ユートピアとの中間 & 昭和5年 & 札幌鉄道局 & $50 人$ & & 0 & 0 & 0 & 0 \\
\hline 30 & 左股巡視小屋 & 幾春別川上流 & 昭和5年 & 帝室林野局岩見沢出張所 & 6人 & & & 0 & 0 & 0 \\
\hline 31 & 天狗岳ヒュッテ & 小樽天狗岳 & 昭和6年 & 小樽スキークラブ & 6人 & & 0 & 0 & 0 & $\Delta$ \\
\hline 32 & 長門七ュッテ & 定山渓白井川上流 長門鉱山跡 & 昭和6年 & 北大スキー部 & 7人 & & 0 & 0 & 0 & $\mathrm{x}$ \\
\hline 33 & 無意根小屋 & 豊平川上流 & 昭和6年 & 北大医学部大野精七 管理·鈴木重雄 & 15人 & & 0 & 0 & 0 & 0 \\
\hline 34 & 室蘭岳ヒュッテ & 室蘭市香川町 & 昭和6年 & 室蘭市役所内室蘭宣伝協会 & 100人 & & & & 0 & \\
\hline 35 & ニセカウシュペ小屋 & 二セカウシュペ山中原 & 昭和6年 & 旭川営林事務所 & 10人 & & 0 & 0 & 0 & $\Delta$ \\
\hline 36 & 雌阿寒営林署番小屋 & 雌阿寒岳剱ヶ峰東方 & - & 阿寒営林所 & 10人 & & 0 & 0 & 0 & \\
\hline 37 & 似様小屋 & 上士別村似樣移民地最奥 & 昭和6年 & 帝室林野局士別出張所 & 20人 & & & 0 & 0 & $\mathrm{x}$ \\
\hline 38 & 日陰沢休泊小屋 & 夕張川奥二股 & 昭和6年 & 帝室林野局夕張出張所 & $30 人$ & & & 0 & 0 & \\
\hline 39 & 美留和第二休泊小屋 & 美留和駅東 $3 \mathrm{~km}$ & 昭和6年 & 帝室林野局弟子屈出張所 & 15人 & & & & & $\Delta$ \\
\hline 40 & 雄鬼頭小屋 ～～～～～～～～ & 奥士別鬼頭沢奥 & 昭和6年 & 帝室林野局士別出張所 & 20人 & & & 0 & 0 & \\
\hline 41 & 十勝岳監視小舎(白銀荘) & 吹上温泉東北方 & 昭和7年 & 北海道庁 管理·富良野営林区署 & 15人 & & & 0 & 0 & 0 \\
\hline 42 & 天塩岳小屋 & 士別村ポンテシオ奥 & 昭和7年 & 帝室林野局士別出張所 & $20 人$ & & & 0 & 0 & 0 \\
\hline 43 & 右股小屋 & 手稲村字右股 & 昭和7年 & 北海道庁秘書課内右股小屋会 & 20人 & & & 0 & 0 & $\mathrm{x}$ \\
\hline 44 & 鳴川の小舎 & 横津岳中原 & 昭和7年 & 日魯漁業会社燭光会スキー部 & $30 人$ & & & 0 & 0 & $\Delta$ \\
\hline 45 & 奥無意根小屋 & 薄別川上流 & 昭和7年 & 有原豊平 & $20 人$ & & & 0 & 0 & \\
\hline 46 & 美瑛忠別造林小屋 & 美瑛御料地 & 昭和7年 & 帝室林野局旭川出張所 & 10人 & & & 0 & 0 & $\mathrm{x}$ \\
\hline 47 & 摩周湖巡視小屋 & 屈斜路湖 & 昭和7年 & 帝室林野局弟子屈出張所 & 10人 & & & 0 & 0 & $\Delta$ \\
\hline 48 & 勝岳荘 & 吹上温泉東北方 & 昭和7年 & 上富良野十勝保勝会 & $50 \lambda$ & & & & 0 & 0 \\
\hline 49 & 冷水小屋 & 札幌岳冷水沢上流 & 昭和8年 & 定山溪鉄道 & $40 \lambda$ & & & & 0 & 0 \\
\hline 50 & 銀嶺荘 & 鐿函峠西北方春香山麓 & 昭和8年 & 北海夕イムス 河合裸石 & $80 人$ & & & & & $\Delta$ \\
\hline 51 & 摩周巡視兼造林小屋 & 摩周湖 & 昭和8年 & 帝室林野局弟子屈出張所 & $35 人$ & & & & 0 & \\
\hline 52 & 甲一線小屋 & 上士別村ペンケ甲一線奥 & 昭和8年 & 帝室林野局士別出張所 & 20人 & & & & 0 & 0 \\
\hline 53 & 奥春別休泊小屋 & 弟子屈～阿寒越道路側 & 昭和8年 & 帝室林野局弟子屈出張所 & $35 人$ & & & & & $\Delta$ \\
\hline 54 & 東日ヒュッテ & 砥石山簏盤ノ沢 & 昭和9年 & 札幌スキー連盟 & $30 人$ & & & & 0 & $\mathrm{x}$ \\
\hline 55 & 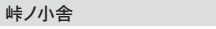 & 小樽定山渓道路の峠 & 昭和9年 & 小樽定山渓自動車会社 & 15人 & & & & 0 & $\mathrm{x}$ \\
\hline 56 & オロフレ山スキー休诱小屋 & オロフレ山西南方羅漢山西方 & 昭和9年 & 室蘭運輸事務所 & 10人 & & & & 0 & $\Delta$ \\
\hline 57 & 滝ノ沢休泊小屋 & 夕張岳西方ペンケモユーパロ川上流 & 昭和9年 & 帝室林野局夕張出張所 & $35 人$ & & & & 0 & $\Delta$ \\
\hline 58 & ユコマンベツ温泉小屋 & 旭岳西南ユコマンベツ川上流 & 昭和10年 & 北海道景勝地協会 & $30 人$ & & & & 0 & $\mathrm{x}$ \\
\hline 59 & 愛山渓造林小屋 & 愛山渓温泉 & 昭和10年 & 旭川森林事務所 & $10 人$ & & & & 0 & $\mathrm{x}$ \\
\hline 60 & 愛山渓上ユッテ & 愛山渓温泉付近 & 昭和10年 & 村上元吉 & $60 人$ & & & & & $\mathrm{x}$ \\
\hline 61 & 夕張岳休泊小屋 & 夕張岳西南白金川上流 & 昭和10年 & 帝室林野局夕張出張所 & 25人 & & & & 0 & $\Delta$ \\
\hline 62 & 登和里小屋 & 上士別村登和里奥 & 昭和10年 & 帝室林野局士別出張所 & 20人 & & & & 0 & $\Delta$ \\
\hline 63 & 咲来小屋 & 上士別村咲来沢岩尾内農地奥 & 昭和10年 & 帝室林野局士別出張所 & 20人 & & & & 0 & 0 \\
\hline 64 & 愛山渓温泉 (旅館) & 安足間駅より16km & 昭和11年 & 村上元吉 & $40 \lambda$ & & & & & $\mathrm{x}$ \\
\hline 65 & 志計礼別休泊小屋 & 弟子屈農地内 & 昭和11年 & 帝室林野局弟子屈出張所 & 40人 & & & & & $\Delta$ \\
\hline 66 & 札友内第二休泊小屋 & 美留和駅西南6km & 昭和11年 & 帝室林野局弟子屈出張所 & 40人 & & & & & $\Delta$ \\
\hline 67 & 摩周第二休泊小屋 & 弟子屈より6km湖側 & 昭和11年 & 帝室林野局弟子屈出張所 & 15人 & & & & & $\Delta$ \\
\hline 68 & 裏鬼頭小屋 & 士別町、天塩川森林鉄道沿線 & 昭和11年 & 帝室林野局第一土別出張所 & 10人 & & & & & 0 \\
\hline 69 & 本流奥休泊小屋 & 夕張川シューパロ川上流 & 昭和11年 & 帝室林野局夕張出張所 & $20 人$ & & & & & 0 \\
\hline 70 & 北海製缶ヒユッテ & 塩谷丸山東麓 & 昭和12年 & 北海製缶倉庫会社健康保険組合 & 20人 & & & & & $\mathrm{x}$ \\
\hline 71 & ニセコ山の家 & 二セコアンヌプリとイワオヌプリとの鞍部 & 昭和12年 & 札幌鉄道局 & 44人 & & & & & 0 \\
\hline 72 & 似樣移民地小屋 & 似峡川流域移民地 鉄道終点 & 昭和12年 & 帝室林野局第一士別出張所 & 10人 & 凡 & 例 & & & $\mathrm{x}$ \\
\hline 73 & 跡佐登第四休泊小屋 & 川湯より4km東北 & 昭和13年 & 帝室林野局弟子屈出張所 & 15人 & & & & & $\Delta$ \\
\hline 74 & 夕映橋休泊小屋 & 奥春別休泊小屋の4km西側 & 昭和13年 & 帝室林野局弟子屈出張所 & $30 人$ & & ：使月 & & & $\Delta$ \\
\hline 75 & 天塩岳左股小屋 & 天塩岳山麓 森林鉄道終点から $4 \mathrm{~km}$ & 昭和13年 & 帝室林野局第一土別出張所 & $30 人$ & & : 不明 & & & 0 \\
\hline 76 & トムラウシ山避難小屋 & 飘簕沼畔 & 昭和15年 & 北海道景勝地協会 & $10 人$ & & & & & $\mathrm{x}$ \\
\hline 77 & 網走越第一休泊小屋 & 美幌峠の下国道 & 昭和15年 & 帝室林野局弟子屈出張所 & $15 \hat{\jmath}$ & & ：使用 & 丕可 & & $\Delta$ \\
\hline 78 & 和琴休泊小屋 & 和琴温泉付近 & 昭和15年 & 帝室林野局弟子屈出張所 & $60 人$ & & & ため & & $\Delta$ \\
\hline 79 & 勇駒別山の家 & 旭岳山麓湯沼の畔 & 昭和15年 & 帝室林野局旭川出張所 & $26 人$ & & & & & 0 \\
\hline 80 & 美瑛富士避難小屋 & 美瑛富士南側 & 昭和15年 & 帝室林野局旭川出張所 & $14 \lambda$ & & & & & $\mathrm{x}$ \\
\hline 81 & 毛無山ヒユュッテ & 毛無山〜小樽峠の中間 & 昭和16年 & 小樽スキ一連盟 & & & & & & $\Delta$ \\
\hline
\end{tabular}


山麓、圓山、藻岩山附近にまたがる広大なスキー練習場と大倉山シャ ンツェ、また小樽中心市街地に近い花園公園、小樽高商附近、天狗 山附近、潮見臺に点在するスキー練習場、天狗山シャンツェ、高商シャ ンツェ、小樽シャンツェ、樽中シャンツェなど 4 つのジャンプ台が 確認でき、スキーコース網が札幌、小樽の市街地と接続する場所に おいて、スキーの練習や競技を行う場が整備されている。「ニセコア ンヌプリを中心とするスキーコース圖」では、俱知安町、岩内町、 蘭越驛、昆布驛、狩太驛、比羅夫驛、小澤驛を拠点として、新見温泉、 昆布温泉、青山温泉、湯本温泉、山田温泉等を結ぶスキーコース網 が『スキーとスケート』(大正 13 年) 掲載のスキーコース図よりも 広範囲に描かれている。山小屋は昆布温泉附近に休熄小屋が 1 軒 $^{34)}$ 記載されているのみで、温泉がネットワークの中継点となっている 点と、温泉周辺にスキー練習場が分布している点が特徵的である。

『札幌附近のスキーコース圖』(北大スキー部 昭和 10 年)（図 1 ）は、 冒頭で触れた札幌・小樽・定山渓広域エリアを描いたスキーコース 図で、山岳、鉄道駅、スキーコース、スキー練習場、山小屋が図示 されている。これまで鉄道省又は札幌鉄道局によって作成されたス キーコース図には、省線ではない定山渓鉄道沿線のスキーコースに ついては、記述はあるが図示はされていなかった ${ }^{35}$ 。本図により、 大正 15 年のパラダイスヒュッテ建設から僅か 10 年の間に、札幌・ 小樽・定山渓の広域にまたがるスキーコース網と “山小屋の連鎖”が、 概ね形成されていたことを確認できる。

『スキー北海道』(札幌鉄道局 昭和 13 年) は、戦前における北海 道のスキーに関する旅行案内書の中では最も詳しい。横津岳附近、 ニセコアン附近、小樽附近、札幌附近、定山渓付近、十勝岳附近、 大雪山彙、名寄附近他について、限られた範囲ではあるがスキーコー ス略図が掲載、主たる山岳やスキー場について記述されている。 ${ }^{36)}$

昭和 5 年から 13 年の間には、民間によるスキーに特化した旅行案 内書も多数発行されている (表 2$)$ 。れれら案内書の内容は、札幌 鉄道局発行のものと類似しているが、この時期に民間から多くの案 内書が出版されたことは、一般大衆が北海道のスキーに寄せた関心 の高さを裏付けるものと言えるであろう。

以上から、戦前の北海道における主要なスキーエリアが、ほぼか たちづくられたと考えられる昭和 10 年頃の様子を見るため、札幌鉄 道局発行の『スキーコース図』(昭和 9 年) と『スキー北海道』(昭 和 13 年) によって、スキーコースの所在を 11 エリアに分けて整理 しスキー場所在駅と共に図示した（図 6)。図 6 と表 1 を合わせて見 ることで、スキーコース網と山小屋の関係について、以下のことが わかる。札幌・小樽・定山渓エリアには、スキーコースと関連をも つ山小屋が 20 軒あり、その内、民間企業・個人・北大・スキー連盟 によるものが計 15 軒、秩父宮 1 軒、札幌鉄道局 1 軒、林野局 2 軒、 北海道庁 1 軒から、このエリアの山小屋建設は、北大や民間を主体 とした様々な担い手によって進められたと言える。20 軒の内 18 軒は、 大正 15 年から昭和 9 年の間に集中的に建設されている。大雪山彙に は、スキーコースと関連をもつ山小屋が 7 軒あり、この内、林野局・ 林務課が 4 軒、民間が 3 軒である。十勝連峰には同様の山小屋が 6 軒あり、林野局・林務課 4 軒、民間 2 軒である。大雪山彙 7 軒の内 5 軒、十勝連峰 6 軒のうち 5 軒が、昭和 10 年までに建設されており、 両者は、札幌・小樽・定山渓一帯にやや遅れながらも、ほぼ同時期 に山小屋が官と民によって整備されたことがわかる。ニセコアンヌ
プリ附近については、点在する温泉がスキーコース網の拠点となっ ているため、羊蹄山石室とニセコ山の家 2 軒しか建設されていない。 他にスキーコースとの関連が確認できるのは、函館附近と室蘭附近 に各 1 軒である。その他に、弟子屈 14 軒、士別・上士別 9 軒、空知 6 軒などの山小屋があるが、すべて林野局・林務課によるもので、ス キーコースとの明らかな関連は認められない。

\section{4. まとめ}

表 2 は、本研究で調查対象とした旅行案内書とスキーコース図を、 スキー発達史の要点と共に年表にしたものである。以下に、大正期 から昭和期戦前におけるスキーコース網拡充に関連した地域の形成 とその背景について、スキーコース網形成との関係から䌕める。

北海道において近代スキーが発祥した明治 45 年は、すでに函館、 札幌、旭川、釧路を結ぶ幹線鉄道が敷設され、さらに道北と道東方 面にも延伸される時期であった。当時スキー界をリードしていた札 幌と小樽の両市街地郊外から始まったスキーコースは、大正期にま ず函館本線上の軽川駅附近や昆布駅附近へ、続いて空知、旭川附近、 留萌、網走、野付牛へと鉄道駅を起点にしながら広がった。札幌と 小樽間では、大正 15 年に北大スキー部が建設したパラダイスヒュッ テを端緒に、次々と山小屋が建設され、スキーコース網はこれらを 拠点に南部の山岳地帯に広がり、昭和 10 年頃には、主に北大と民間 が所有する 20 軒の山小屋を有し、定山渓に及ぶ広範囲なものとなっ た。札幌や小樽と関係の深いニセコアンヌプリ附近では、大正 8 年 から北大スキー部の合宿が行われるようになったことが契機となり、 昭和 9 年までに温泉を拠点としたスキーコース網が形成された。大 雪山彙と十勝連峰でも、小樽・札幌にやや遅れながらも、官と民に よる山小屋と温泉を拠点とするスキーコース網が形成された。その 他にも、昭和 10 年頃の北海道には、広くネットワークまでは形成し ないものの、鉄道駅や市街地と結びついたスキー練習場、山岳単独 のスキーコースを多数確認できる。

一方、大正 9 年に「札幌と小樽の中学校スキー大会」(北大スキー 部主催）が開催されたことにより、同年は日本における競技スキー 元年と見なされている ${ }^{37}$ 。同年、札幌近郊の三角山山麓ツッジ山の 仮設シャンツェにおいて第 1 回ジャンプ大会が開催、大正 11 年 12 月には、三角山にはじめての固定式シャンツェの工事開始、以降、 札幌と小樽の近郊に多くのジャンプ台が建設される ${ }^{38)}$ 。大正 12 年に は、小樽スキー俱楽部が北大スキー部と小樽高商スキー部の支援を うけることを条件に、第 1 回全日本スキー選手権大会（日本体育協 会主催）が小樽で開催され ${ }^{39)}$ 、大正 14 年 2 月全日本スキー連盟（SAJ） 設立、翌大正 15 年 2 月 SAJ は国際スキー連盟（FIS）に加盟、スキー の全国的な組織体制が整うが、SAJ 主催の全国大会開催地を見ると、 昭和 3 年の第 6 回全日本スキー選手権札幌大会から昭和 18 年まで、 ほぼ毎年札幌または小樽において全日本スキー選手権大会又は全日 本学生スキー選手権大会が行われている ${ }^{40)}$ (表 2)。また、社会情勢 の悪化により中止されたが、昭和 15 年には札幌において冬季五輪の 開催が準備されていた。このように、大正期から昭和期戦前の札幌 と小樽は日本のスキー発展の先進的かつ中心的な舞台であった。

旅行案内書におけるスキーの紹介は、管見した中では、鉄道院に よる大正 7 年『鉄道旅行案内』から始まる。鉄道省は、大正 13 年か らスキーに特化した案内書やコース図を発行するが、昭和 6 年を最 


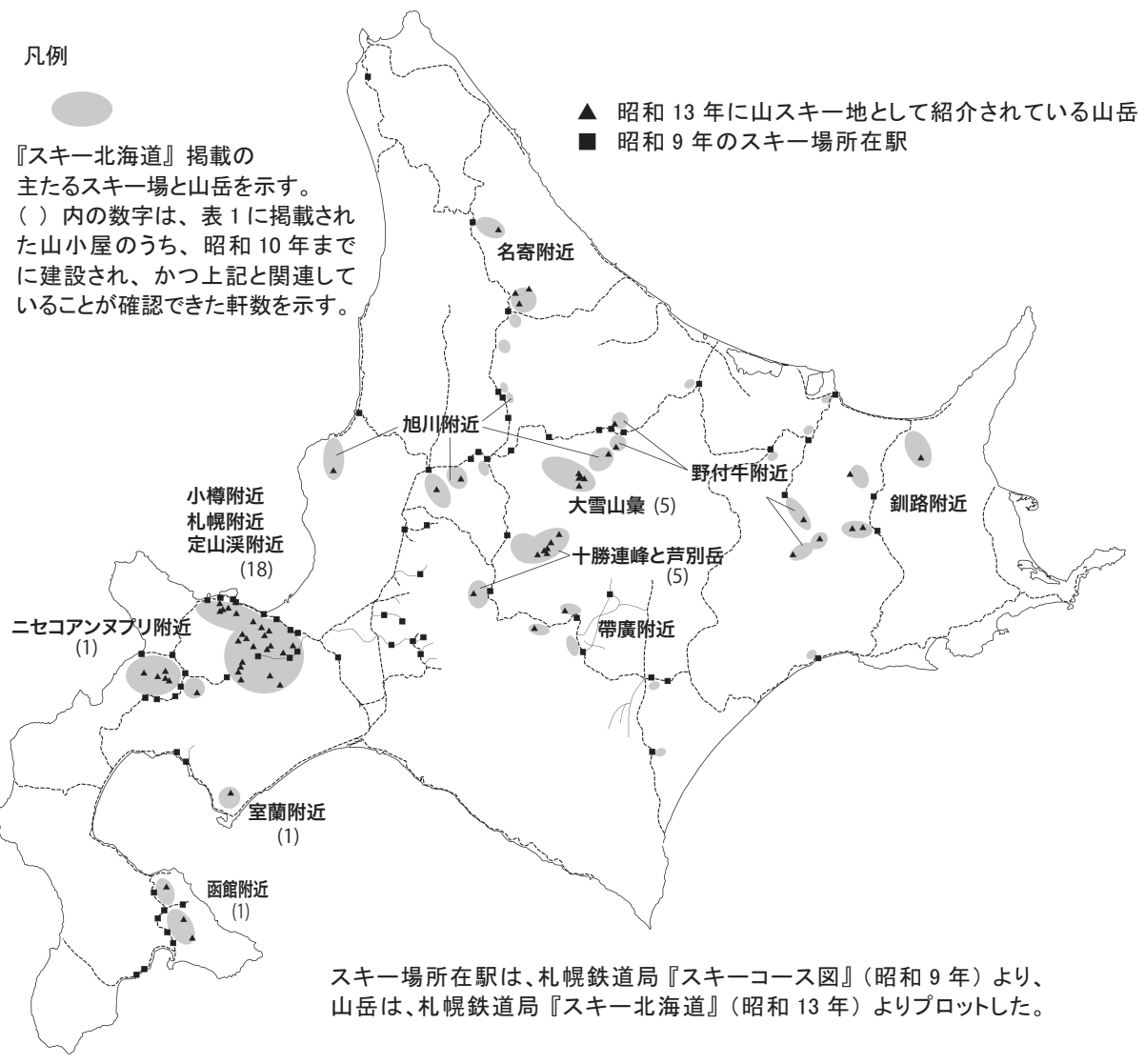

後に見られなくなる一方で、これと入れ替 わるように、札幌鉄道局と民間によるスキー 案内書が、昭和 5 年から日中戦争開始後の 昭和 13 年にかけて多数発行される。これら の案内書には、各地がスキー客で賑わう様 子が記述され、この時期に北海道のスキー コースが広く紹介され、一般に受け入れら れたことが伺える。

以上から、スキーという新しい文化の導 入とスキーコース網の形成によって、昭和 10 年頃の北海道において、独自性をもった 札幌・小樽・定山渓、ニセコアンヌプリ、 大雪山彙、十勝連峰の 4 大スキー地を中心 とする冬期の山岳空間が、雪国の生活文化 と密着し、多くの観光客を迎え入れる活気 あふれる場であったことが明らかになった。 大正期から昭和期戦前におけるスキーコー ス網と地域の形成と発展の背景として、鉄 道網と温泉の充実、北大と小樽高商スキー 部を中心とする先導的な活動と大正 14 年以 降のスキー連盟によるスキー大会、民間に 多くの山小屋の建設、旅行案内書を通じた 活発な広報活動之一般大衆の関心の向上が あり、これは、スキー文化の発展を物語る

図 6 昭和 10 年頃の鉄道、スキー地所在駅、山スキー地

（）内はスキーに関する記述が見られない文献

表 2 北海道におけるスキー発達史概略、SAJ 公認スキー大会、主要スキー案内書とパンフレット

\begin{tabular}{|c|c|c|c|c|c|c|}
\hline \multirow{2}{*}{\multicolumn{2}{|c|}{ 年代 }} & \multirow{2}{*}{ スキー発展史概略 } & \multirow{2}{*}{ SAJ公認スキー大会 } & \multicolumn{3}{|c|}{$\begin{array}{l}\text { 北海道のスキー場に関する旅行案内・パンフレット・図書 } \\
\end{array}$} \\
\hline & & & & 鉄道院 $(\sim T 9) \cdot$ ·鉄道省 & 札晿鉄道局 & 民間 \\
\hline & 1911 & |フォン・レルヒによる高田スキー講習 & & & $\begin{array}{l}\text { (「北海道鉄道路線案内」) } \\
(\text { (「北海道鉄道路線概沇」) }\end{array}$ & \\
\hline $\begin{array}{l}\text { M45 } \\
\text { T元 }\end{array}$ & 1912 & \begin{tabular}{|l} 
フコンン・レルヒにによる旭川スキー講翼 \\
北大スキー部、小樽高商スキー部設立
\end{tabular} & & (「遊覧地案内」) & & \\
\hline T2 & 1913 & & & & & \\
\hline T3 & 1914 & 北大遠藤教授帰国、ノルウエー式スキ一術伝授 & & & & \\
\hline T4 & 1915 & & & (『鉄道旅行案内」) & & \\
\hline T5 & 1916 & & & & (「北海道線各驛要覽」) & (「道内旅行便覧」(北海道應拓殖部) \\
\hline T6 & 1917 & & & (『鉄道旅行案内」) & & \\
\hline T8 & 1919 & & & (「Japan: Traveller's handy guide 1919」) & & \\
\hline T9 & 1920 & 札幌一小樽間スキー駅伝 (北大主催) & & (「温泉案内」) & & \\
\hline T10 & 1921 & & & 「鉄道旅行案内」 & & 「山とスキー」発刊 (北大スキー部、〜S5年頃) \\
\hline T11 & 1922 & 固定式「シルバーシャンツエ」エ事開始 & & ( (The Hot springs of Japan」) & 「䁺附近案内標解説」 & \\
\hline T12 & 1923 & & 第1回全日本スキ一選手権大会(小㭩) & & 「北海道鉄道各驛要覽」 & \\
\hline T13 & 1924 & & & $\begin{array}{l}\text { 「スキーとスケート」 } \\
\text { 「鉄道旅行案内」 }\end{array}$ & & \\
\hline T14 & 1925 & 全日本スキ一連盟(SAJ)設立 & & & |「北海道鉄道各驛要覧」 & \\
\hline T15 & 1926 & SAJが国際スキー連盟(FIS)に加盟 & & & & \\
\hline s2 & 1927 & |昭和恐慌、北大山岳部がスキー部から独立 & & & & 「北海道のスキーと山岳」(加納一郎) \\
\hline S4 & 1929 & 高松宮殿下来道、世界恐慌 & 第2回全日本学生スキ一選手権大会（札幌） & 「スキーへ 昭和五年版」(運輸局) & & \\
\hline s5 & 1930 & 鉄道省国際観光局設置 & 第3回全日本学生スキ一選手権大会(札幌) & & 「北海道スキ一地案内」 & 「スキー適地案内」(スポーツブック） \\
\hline s6 & 1931 & 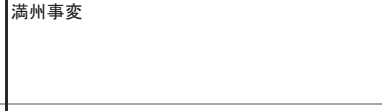 & & $\begin{array}{l}\text { 「スキーへ 昭和六年版」 } \\
\text { (運輸局·日本旅行協曾) } \\
\text { 「温泉案内」 }\end{array}$ & & 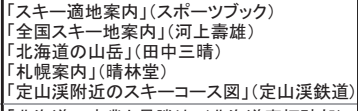 \\
\hline s7 & 1932 & & |第5回全日本学生スキー選手権大会(札幌) & & (「温泉案内」) & 「北海道の産業と景勝地」(北海道應拓殖部) \\
\hline S8 & & & |第11回全日本スキ一選手権大会(札幌) & ( $\ulcorner$ An official guide to Japan $\rfloor)$ & 「スキーへ」 & 「スキ一地案内」(初版) (河上壽雄他) \\
\hline s9 & 1934 & & |第7回全日本学生スキ一選手権大会(札幌) & & 「スキーコース圖」 & 「スキー地案内」(増補版) (河上壽雄他) \\
\hline s10 & 1935 & 「国際スキ一場計画」(鉄道省国際観光局) & $\begin{array}{l}\text { 第13回全日本スキ一選手権大会(札㡢) } \\
\text { 第8回全日本学生スキ一㟟手権大樽) }\end{array}$ & (「Japanese drama」(国際観光局)) & & \begin{tabular}{|l} 
「札㿞附近のスキーコース圖」(北大スキー部) \\
「Winter in Hokkaido」(札幌グランドホテル)
\end{tabular} \\
\hline s11 & 1936 & & & $\begin{array}{l}\text { 「日本案内記·北海道偏」 } \\
\text { 「鉄道旅行案内」 }\end{array}$ & 「雪・スキー北海道」 & \\
\hline S12 & 1937 & 日中戦争 (支那事変) & 第10回全日本学生スキ一選手権大会 (札幌) & & & 「銀嶺の起点定山溪」(定山溪鉄道) \\
\hline $\mathrm{s} 13$ & 1938 & \begin{tabular}{|l|} 
国家総動員法 \\
S15年開催予定夏·冬期五輪(東京·札幌)返上
\end{tabular} & $\begin{array}{l}\text { 第16回全日本スキー選手権大会(札帽 ) } \\
\text { 第11回学生会 (小樽·ニセコ) }\end{array}$ & & 「スキー北海道」 & 「冬山登山とスキーツーア」(新島章男) \\
\hline s14 & 1939 & & 第17回全日本スキー選手権大会」(札幌 ) & & & \\
\hline s15 & 1940 & & & & & \\
\hline s16 & 1941 & 太平洋戦争開戦 & 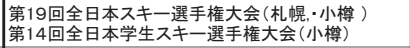 & $\begin{array}{l}\text { (「日本山岳案内第四集」(山兵部)) } \\
\text { 「Japan the official g guide」」(国際観光局) }\end{array}$ & & \\
\hline S17 & 1942 & & & (「日本山岳案内·山岳スキ一」(山岳部)) & & \\
\hline
\end{tabular}


と共に、現代のゲレンデスキーを超えたスケールの大きな地域の観 光資源化の動きとして捉えられるものである。

\section{謝辞}

高澤光雄氏、在田一則氏他、北大スキー部 OB の方々から貴重な史料 の提供、北海道大学大学院角幸博、石本正明両先生から多くの助言 を頂きました。筆者の研究室修士課程学生であった池村菜々氏には、 史料収集と整理を恊働して頂きました。ここに感謝の意を表します。

\section{注}

1) 本研究の対象は、主に山スキーのコースである。調査文献には、「コース、 スキーコース、下リノミノコース、スキー練習場、好スロープ、スキー滑走路」 等の表現が見られるが、本研究ではこれらを総称して「スキーコース」とする。 必要に応じて、スキー練習に適し、まとまった広さを持つスロープを示すた め「スキー練習場」を使用する。他に「スキー場」「スキー地」という表現を、 文献にそのように記載されている場合に、その内容を示すために使用する。

2) 大野精七（1885-1982）: 北大医学部教授。ドイツ、フライブルグ大学留学、 大正 13 年帰国、北大スキー部部長。宮様スキー大会創設や昭和 15 年に予定 され中止された札幌オリンピック開催に尽力。スキーの発展に功績を残した。

3) 山崎春雄（1886-1961）: スイス、チューリッヒ大学留学。ヘルヴェチアヒュッ テ所有名義人。昭和 3 年秩父宮殿来道時に準備委員長、昭和 24 年から 28 年、 日本山岳会北海道支部長。

4) Max Rudolf Hinder(1887-1963) : スイス、フルンテルン（現チューリッヒ市 の一部）出身の建築家。大正 14 年来札、パラダイスヒュッテ、ヘルヴェチ アヒュッテ、空沼小屋を設計。昭和 2 年横浜に移転、昭和 15 年ドイツへ移住。

5）大野精七『北海道のスキーと共に』(1971) p. 68, p. 372

6) 中浦皓至「北海道における近代スキーの発達に関する歴史的研究」(北海道 大学大学院教育研科修士論文、2001）p. 4。日本へのスキー伝来については、 北大予科ドイツ語教師ハンス・コラーによる明治 42 年春のスキー取り寄せ、 同年旭川第七師団長上原勇作による北鎮中への寄贈などがあるが、中浦は、 集団性、継続性と技術向上、組織性と発展という条件から、フォン・レルヒ による高田のスキー講習会を “日本における近代スキーの発祥”としている。

7）小澤丈夫、笹岡歩「スキー場に隣接する地域の形成過程 富良野市北の峰町 を事例として」（日本建築学会学術講演梗概集、2008）、池村菜々、小澤丈夫 他「スキー場とスキー場に隣接する地域の形成過程と空間構成 - ニセコひ らふ地区を事例として」（日本建築学会北海道支部研究報告集、2008）など。

8) 小川勝次『日本スキー発達史』（朋文堂、1956）、加納一郎『北海道のスキー と山岳』(北海道山岳会、1927) 北海道帝國大學文武會スキー部『記念 : 創 立拾五年』(1926)、同『部報：1933』(1933)、北海道スキー部O B 会『北海 道大学スキー部七十年史』(1982)、北海道スキー連盟『創立五十周年記念誌』 (1982) など

9) 森本光彦「Berg Hütte とSki Hütte に就いて」( 北海道大学工学部建築工 学科卒業論文、1951)

10) 白坂蕃「中央高地栂池高原における新しいスキー集落の形成」（地理学評論、 1991)、呉羽正昭「観光地開発に伴う首都圏周辺山村の変容 - 群馬県片品村 の例 -」( 愛媛大学人文学会創立 20 周年記念論集) など

11）前掲書 6)。中浦皓至の著書には『日本スキーもうひとつの源流』(北海道 大学出版会、1999）もあり、1925 年に日本スキー連盟が設立され、客観的 な史実が記録されるまでの著書の多くが、後の同連盟指導者による回想録で、 出典が不明な記述や誤りを含むことを指摘している。中浦論文は、当時の小 樽新聞と北海タイムスを中心とする調査により、多くの史実を明らかにして おり、大正期のスキーに関する史実を把握するために信頼できると判断した。

12）鉄道省は、大正 9 年まで鉄道院。札幌鉄道局は、大正 8 年まで北海道鉄道 管理局、大正 8 年以降札幌鉄道局。明治 45 年には、すでに函館、札幌、旭川、 釧路間の鉄道幹線が整備され、さらに道北と道東方面に鉄道が延伸される大 正期と昭和期戦前において、両者は多くの旅行案内書を発行した（表 2)。

13）本稿では、旅行ガイドブック、パンフレット、スキーコースの具体的な案 内が記載されている書籍を総称して旅行案内書と表現する。

14）日本山岳会『山日記』初輯 1930（昭和 5）年、同第 3 輯 1932 （昭和 7）年、 同第 7 輯 1936 （昭和 $11 ）$ 年、同第 14 輯、1948（昭和 23 年）年。『山日記』は、 昭和 5 年創刊、昭和 17 年第 13 輯迄毎年発行。第二次大戦によって一時休刊、 昭和 23 年に第 14 輯発行、昭和 59 年発行の第 50 輯をもって廃刊。同書は、 登山者の安全と利便のため、山小屋の継続的な調査を地元各山岳関連団体に 依頼、最新状態を毎年更新しており、史料として信頼性が高いと判断した。
15）稲田昌植、野村竜吉、荒木忠郎、徳岡松雄、二木春松、角倉邦彦

16）鉄道逓信管理局、札幌中学（現札幌南高校）、北海道師範（現北海道教育大 学札幌校)、北海中学 (現北海高校)

17）北大スキー部は、大正 2 年 12 月 22 日蝦夷富士（羊蹄山） 6 合目まで、12 月 31 日から翌 1 月 1 日に富土山登頂に成功するなど、すでに本格的な冬山 登山の基本を徹底的に実施していたと中浦は記している。教程書については、 『スキー術教程』大正 7 年 11 月初版、『Alpen Zeitung』(大正 9 年)、『山と スキー』（板橋敬一、加納一郎、大正 10 年初版、昭和 5 年迄継続）などを出版。

18）松丸乙近 (小樽高女)、佐藤林造（同）奥谷甚吉（小樽新聞）

19) 前掲書 6) 第 2 章、3 章

20) 前掲書 6) 第 3 章

21）これ以前の明治 45 年鉄道院『遊覧地案内』は、全国の遊覧地を鉄道旅行す るための案内書で、主要路線ごとに各駅の人口、公園、神社、農場、温泉な どが簡潔に記述されるが、スキーには触れられていない。筆者が管見した中 では、全国で初めてスキーが紹介されるのは、大正 4 年発行の本書である。 信越線高田駅の欄には「冬期スキー練習場、西二十町」と記述され、妙高山 下、高田金谷山の写真が掲載されている。

22）昭和 9 年 1 月発行の図 2 では、青山温泉がイワオヌプリ北側にあるが、こ れは後に移転されたもので、この時点の青山温泉は昆布温泉の位置にあった。

23）同書では、折り込みの北海道全体の鉄道地図と共に、各駅の地方史、人口、 戸数、主要産物、森林、農場、官公庁、学校、会社、倉庫、温泉、河川、旅 館等について、鉄道省発行の案内書よりも詳細に記述されている。

24) 前掲書 9) p. 124、p. 127

25）角幸博「マックス・ヒンデルと田上義也 - 大正・昭和前期の北海道建築界 と建築家に関寸る研究」（北海道大学工学研究科博士論文、1996） p. 215

26) 前掲書 25) p. 216

27）前掲書 25) p. 218

28）前掲書 5)（p. 372）によると、「(秩父宮殿下は）大野スキー部長のスキー ヒュッテの連鎖の説明に大変御満足遊ばされ、殿下御自身もその連鎖のいず れかにヒュッテ建設のご希望を述べられた」とされている。

29）戦前の北海道の山小屋については、山日記を原史料にして高澤光雄が「「山 日記」に掲載された戦前の山小屋」(「北海道山岳」日本山岳会北海道支部、 1999、p. 145-p.152）にて纏めているが、筆者は『山日記』原本にあたるこ とにより、戦前の北海道に建設された山小屋リストを作成した。

30）前掲書 9） p. 123-124によると、大正期の山小屋は、積雪期の利用に対して は甚だ不完全なものでしかなかった。

31）蝦夷富士附近は、比羅夫駅を拠点とした「スキー初心者よりは、登山スキー の練習に適する」スキー地として紹介されている。

32）旅館について「百五十人位収容出来、乾燥室の設備は最も良い、殊に玉突 きなどの設備があるのは山奥には過ぎてるる」と記述されている。

33）同使用規定によると、使用期間が「毎年十二月一日ヨリ翌年四月末日迄開 設スルモノトス」とされており、使用券が甲（宿泊用）と乙（休蒩用）に区 別され、札幌驛 (甲のみ)、銭函驛（甲乙）、小樽駅（甲のみ）で購入可能と 記載されていることから、同山小屋が、主に冬季においてこれら 3 駅から山 に入る一般者の宿泊又は休憩を目的としたものであることがわかる。

34）本休䕀小屋は、『山日記』には掲載されていない。

35）昭和 6 年に定山渓鉄道が、定山渓付近のスキーコース図を発行しているが、 内容は簡単な略図程度に留まっている。

36) 本書は昭和 12 年支那事変と国家総動員法後に出版。前書きに、「恵まれた 環境の中に普及されたスキーは競技方面で（中略）“スキー王国北海道”を 築き上げ、スキー登山の発達亦著しく、既に冬期間には缺くことの出来交 通機関として實用化してみる。（中略）スキーを馳つて活躍する夥しい人々 に老若男女の別なく（中略）可憐な少年少女の元氣な姿など雪國の意氣と健 康との象徴であらう。」とあり、スキーが普及したことが伺える一方で、「今 や長期建設の秋、國を擧げて人的資源の強化を圖る時スキーの普及發達こそ 冬期雪國の國民の心身鍛錬に最適なばかりでなく、軍事的にも重要な意義を 持つことを自覺し、スキーの普及發達を圖らねばならぬのではなからうか。」 とあり、スキーを国民の心身鍛錬の手段と考える時代に入ったことが伺える。

37）小樽水産学校前をスタート、札幌の北大をゴールとするスキー駅伝。記録 重視のスキー競技会の始まりとされる。札幌一中、札幌二中、北海中、小樽中、 小樽水産、小樽商業、北海商業の 7 校が参加。札幌師範が欠場。前掲書 6) p. 88 38) 前掲書 6) p. 90

39) 前掲書 6) p. 150

40）北海道スキー連盟『創立五十周年記念誌』（1982）p. 118 